\title{
An Overview of the Nigerian Defense Policy and the Challenges against Terrorism
}

\author{
David Oluwafemi Bodunde, Noah Opeyemi Balogun \\ Department of Peace, Security and Intelligence Studies, Afe-Babalola University, Ado-Ekiti, Nigeria \\ Email: balogunnoah@abuad.edu.ng
}

How to cite this paper: Bodunde, D. O., \& Balogun, N. O. (2019). An Overview of the Nigerian Defense Policy and the Challenges against Terrorism. Open Journal of Political Science, 9, 525-537.

https://doi.org/10.4236/ojps.2019.93030

Received: March 4, 2019

Accepted: June 18, 2019

Published: June 21, 2019

Copyright $\odot 2019$ by author(s) and Scientific Research Publishing Inc. This work is licensed under the Creative Commons Attribution International License (CC BY 4.0).

http://creativecommons.org/licenses/by/4.0/

\begin{abstract}
From independence to the present, Nigeria aims and aspiration in its national defense policy is to maintain peace with its neighbors, security and defend its territorial integrity. With the principles of Afrocentricism and neighborliness, it is of no doubt that Nigeria detests war. However, global issues have transcended maintenance of peace without viable economy, good governance technology and motivation among which are becoming a challenge against Nigerian defense policy. Current contemporary issue of terrorism poses serious challenge on Nigeria defense policy. It is true that Nigerian defense policy addresses military capability and deterrence against external threat but it lacks the necessary requirements to back it up in challenging terrorism. It also appears that Nigeria defense policy is heavily relying on the matrix of military capability as a source of deterrence rather than the sum total of superior technology/excellent infrastructure, motivation and resources to fight terrorism. The Nigerian defense policy also failed to take cognizance of the revolution in military revolutionary affairs in which new dimension of fighting war through asymmetric or ultra-irregular warfare and terrorist grand strategy of kidnapping and suicide bombing have overtaken the place of military conventional warfare. The paper attempts to trace the historical precedent of the Nigerian defense policy, its role and challenges in combating terrorism. The paper made use of observation and secondary data and also concluded that it is not the Nigerian defense policy on paper that is faulty but it lacks the operational mechanisms of combating terrorism such as good and purposeful leadership, motivation, resources and moving with the global trend of revolution in military warfare. The paper came out with suggested solutions that government must use human and resources security, de-politicization of terrorism, moving with the global trend of revolution in military affairs with collective global security to fight terrorism.
\end{abstract}

\section{Keywords}

Defense Policy, Terrorism, Security, Revolution in Military Affairs, Globalization 


\section{Introduction}

The Nigerian Defense Policy is an integral part of its foreign policy. The foreign policy of a nation includes its territorial defense policy against external aggression. However, Nigeria after the end of the Civil War in 1970 saw an irreversible dynamic towards acceptance of a realist philosophy in Nigeria's defense community, which views military power and the basis of diplomacy and of all contractual obligations beyond the boundaries of the state. Presently Nigeria is experiencing fundamental security issues in areas of violence, armed robbery, kidnapping, human trafficking, compounding this crises, also are radicalized religious and regional youths movement namely movement for the emancipation of Niger Delta (MEND), Oodua People's Congress (OPC), Movement for the Actualization of the Sovereign State of Biafra (MASSOB) Maitasene insurgency and the current Boko Haram sect that launched polemical offensive in Nigeria through terrorism and insurgency (Alabi, 2013).

Without doubt a state with lack of basis capabilities such as political, economic, and industrial and technology to establish strong national defense and security structures undoubtedly are exposing itself to security risk. The importance of this is that the defense structure and policy provide the necessary guiding principles to national priorities. According to Bassey \& Dokubo (2011) the defense policy of Nigeria among all odds still remains problematic. This involves the imperative necessity of making explicit judgment about the scope and direction of defense policy commitments as well as the conditions for processing the ability (structure, magnitude and institutional parameters of Nigeria's defense establishment) to meet these functions and challenges. This paper explains the phenomenon of terrorism and the impact of Nigeria's defense policy in checkmating it and also recommends new management policy strategies that could successfully tackles this problem.

The main objectives of this study centers on the role of the Nigeria's defense policy on terrorism. Other objectives are to study: the extent of terrorism threat on Nigeria's security; the causes and fundamental issues that promote terrorism; the Nigeria's defense policy and the changing environment; and the proposal and the problems of the Nigeria's defense policy in checkmating terrorism with necessary recommendations. After the cold war, the dynamic issues of threat have pervaded the world, Nigeria inclusive. However, it appears that only the issue which is terrorism is defiling security policy of Nigeria as if there can be no solution.

Again the security policy of Nigeria appears to be lacking the basic capabilities such as: political, economic industries and technology to establish a strong nature defense and security structures which may make Nigeria expose to threat challenges that could undermine its independence and development. Moreover, it appears as if there is no policy framework to harmonize its national interest with the available resources thereby making its defense policy a mockery in the face of terrorism. The study started with conceptual clarification of key concepts 
in the study, explored the architecture of Nigeria's defense policy against terrorism viz a viz the challenges, and looked at the implication for national security.

\section{Conceptual Clarification}

\subsection{Defense Policy}

The aims of the policy makers to design strong defense strategy and national security slimmed from its history. Nigeria is located in the midst of weaker countries in terms of human and natural resources in which Nigeria could not define its natural interest beyond these considerably. Since independence, Nigeria policy has been guided by two principles of Afrocentricism and neighborliness. (Fage, 2016). Theoretically and practically, Nigeria concerns itself to military preparedness on national security and defense to avoid war through diplomacy and deterrence. Nigeria armed forces will also possess the capability of defending the nation's territory and its people. The military will also possess the capability of applying military fire power and deterrence against potential enemies.

Deterrence and force projection constitute the elements and principles in which Nigerian national defense operates. According to Synder (Okwori, 2012), deterrence means "discouraging the enemy from taking military action by posing for him a prospect of cost and risks which outweigh its prospective gainsDeterrence works on the enemy's intention, the deterrence value of military forces in their effect in reducing the likelihood of enemy's moves". The constitution of Federal Republic of Nigeria (FRN, 1999) stressed the need for legitimate and organized instruments of coercion within its border with a view to warding off threat internally and externally. This calls for the need to have versatile defense in order to sustain its sovereignty. Section 217(2) of the constitution enumerates the role of the armed forces as:

1) Defending Nigeria from external aggression

2) Maintaining its territorial integrity and securing its borders from the violation on land, sea or air.

3) Suppressing insurrection and acting in aid of civil authorities to restore order when called up to do so by the president but subject to such condition as may be prescribed by an act of the national assembly and

4) Performing such function as may be prescribed by an act of the national assembly.

However, the final policy that came out in 2014 also considered the following in the defense policy:

1) Strategic review

2) Risk and challenges

3) Strategic response

4) Defense Management operation

5) Resource support and

6) Civil military relations.

The 2006 edition of the Nigerian defense policy provides the theoretical basis 
of the national defense policy as "designed to guarantee national security and threat by deterring external threats and aggression". While the primary concern is to avoid war through diplomacy and deterrence, the nation will ensure that the armed forces possess the capability to successfully defend the Nigerian territory and her people. The choice of Nigeria's conventional defense strategy can be seen from its historical evolution. Its geostrategic location and national interest here acts responsible, Nigeria is surrounded by weaker countries in terms of human and financial resources, it was able to define its national interest only within the scope of Afrocentric. Another is good neighborliness. In view of this it limits its defense policy to military preparedness as the vital ingredients of national security and defense. Its national defense is to avoid war through diplomacy and deterrence in which the nation must ensure that the armed forces possess the capability to successfully territory and people (NNDP, 2006). External factors also determine the shape of Nigeria's security decision making process among which are global approach to peace, the place of Africa in the world order, border security, foreign military influence and terrorism. This is the more reason why Nigeria designs its concentric circle of foreign policy in dealing with its neighbors and global world entirely within the matrix of international relations, national defense and collective security (Asobie, 2014).

\subsection{National Security}

Security is a significant concept and issue that connotes many meanings to intellectuals and practitioners. Its meanings are ambiguous with its scope expanding every day. Security is diversified into many issues such as economic security, food security, national security, personal security and so on. Hughes (2006) reiterated the importance of environmental security which should be based on agenda rather than concentrating on one issue. The agenda to him are multifarious ranging from threats, H.I.V, economic development, health, war and peace. He believed that security can be achieved through conscious effort of some particular actors who can shape the world in a desired way. According to William (2008) security is associated with the alleviation of threats to cherished values. To Ogaba (2010) security has to do with freedom from danger or threats to a nation's ability to protect and develop itself promotes its cherished values and legitimate interest and enhance the wellbeing of its people. Thus, internal security could be seen as the freedom from or absence of those tendencies which could undermine internal cohesion and corporate existence of a country and its ability to maintain its vital institution for the promotion of its core values and socio-political and economic objectives as well as meeting the legitimate aspiration of the people.

Again there is need to point out that state always need to recognize the enormous dangers of international environment poses to its security survival. This makes the conception of National security falls between two extreme views. Security to be achieved through unconventional matrix by the application of force through military efforts as a strong agent of deterrence or the conventional 
defense strategy through diplomacy, dialogue, good governance and defense strategy to defense its territorial integrity. However, Okwori (2012) holds that "national security cannot and in fact should not be reduced to the accusation of military hardware alone".

\subsection{Terrorism}

There is an argument on the definition of terrorism. It still remains unresolved because the arguments centers on who is a terrorist. Those labeled terrorist rejected it and see themselves fighting for nationalist cause. Governments of the day even terrorize their political opponent under the excuse of subversion, hate speech and insecurity. However, Fried (1984) defined terrorism as the treat or use of political purposes by individuals or groups whether acting for or in opposition to establish governmental authority when such an action are intended to influence a targeted group other the immediate victim or victims. According to Woods (1983) terrorism is the weapon of those people that are not prepare to use legal means but violence to achieve a desired goal.

Apata (2011) opined that international terrorism refers to coercive violence conducted with the support of a foreign government or organization and or directed against foreign nationals or government. The federal bureau of intelligence define terrorism as unlawful use of force of violence against person or property to intimidate or coerce a government, civilian population or any segment thereof in furtherance of political or social objectives, (Whittaker, 2007). Terrorism is international in scope, facilitated by globalization and self-evident that not something any country can deal with by natural strategy alone the chief aims of terrorist are to oust any government not well composed to their ideology, cause political instability in any country, set their machinery in motion in the destabilized country, secure independence from western civilization of forming their own government through internal revolution.

\section{Theoretical Background}

The Theory in this paper is anchored on national interest. The Defense policy of a nation is an embodiment of its foreign policy. What is paramount to these policies is national interest. It is the national interest that a nation takes into consideration before forming its defense policy. The interest embodied the security of its citizens and its defense capabilities against external aggression-Considering the fact that the foreign policy of a nation varied, there must be hierarchically ranking set of objectives to reflect its national interest priority which any country needs to sustain at all cost both internally and at international levels. Holsti (1983: pp. 19-35) in support of this, postulated that:

"The foreign policy of a nation consists of varied but usually hierarchically ranked set of objectives which the government intends to achieve in its interaction with other nations".

According to Bassey \& Dokubo (2011) relating the rule of the military in defense policy he said; reduce to fundamentals the crux of defense policy is the re- 
lation of force national purposes. The latter involves basic values, the enhancement of which is often considered the high priority goals of state foreign policy. It follows therefore, that as an instrument of foreign policy, the first policy is concerned with the provision, deployment and use of military power to facilitate the provision and promotion of perceived national interest of the state in the international arena. Such national interest may contain core values which are near constant and few in number, involving the survival of society and its population, political sovereignty and territorial independence

Morgenthau (1973: p. 9) also supporting the importance of national interest thus; "No action can have a true guide as to what it must do and what it needs to do in foreign policy without accepting national interest as her guide". In other word, national interest from Morgenthau can be constructed as a true guide as to what a nation must do and what it needs to do in foreign policy. In totality, national interest stands as a guide to a nation's foreign policy formulation and decision making. Again, national interest may be seen as the compass, operational and analytical guide which a nation relies in its interactions with other nations for some expected benefits. Morgenthau moved further to opined that: "The meaning of national interest is survival-the protection of physical political and cultural identity against encroachments by other nation states". National interest is a vague and ambiguous term that carries a meaning according to the context in which it is used. State-men and policy makers use it in a way suitable for them to justify the action of their state. Hitler justified expansionist policy in the name of German national interest. US justified its own national interest to go in for the development of more destructive weapons by building up nuclear base at Diego Garcia in meeting the challenge posed by USSR as well as protecting US against in India Ocean.

Morgenthau also noted that the vital components of the national interests that a foreign policy seeks to secure are; Survival or identity. He subdivided identity into three parts; Physical, Political and Cultural identity. Physical includes territorial identity, political identity means politico-economic system and cultural identity stands for historical values. The means of achieving national interest are through diplomacy, propaganda, economy, alliance and treaties, coercive means such as the use of military power against external threat such as international terrorism. According to Dyke, national interest means "The values, desires and interest which states seek to protect or achieve in relation to each other desires in the part of sovereign states".

(https://www.yourarticleliberary.com/international-politics/national-interestme aningcomponents-andmethods/48487). National interest of a nation is not the interest of a particular regime or elite but the interest of the whole nation in order to sustain the political stability of such period. In other words, national interest is not static to a regime. The more reason why Adeniji (Guardian, 2003: A2) opined that:

"National interest as I have always insisted should not be conceived as the interest of any particular regime. In other words, you bend foreign policy to sus- 
tain the overall interest of the people of that country and not just the interest of the regime or elite". Moreover a country's foreign policy revolves around its national interest while the primary responsibility of all foreign policy makers is to articulate their country's national interest and to relate them to those of other nation's states (Bodunde, 2006). The relevance of this theory enables the leadership of a country with his cabinet to define in broad term the national interest of a nation. It also enables a nation to focus on the areas of national interest such which they could derive comparative advantage. Moreover, national interest enables a nation to preserve its values, security and survival among the comity of nations. The concept has also become one of the dominant paradigms in studying political phenomenon. This is because beings are prime movers of international politics which rest on national interest.

The shortcomings of national interest rest on the fact that leaders may shape national interest to personal interest as it is opposed to national policy. Moreover, nations may hide national interest to find their justification in political decision as opposed to public opinions. Various policies that form national interest are policies of the leaders therefore, national interest may be abused by the leaders at the helm of affairs

\section{The Nigeria's Defense Policy against Terrorism: The Challenges So Far}

The Nigerian foreign policy also gives priority to its defense policy. From its foreign policy the security of the operational environment started from the epicentric to the ring countries, west Africa sub region, African political milieu, the organization of petroleum exporting countries and non-aligned countries and the international system at large. Epicentric is concerned with the Nigerian defense and protection of its territorial integrity, sovereignty, and economic interest against aggression whether internally or externally. The security concerns of our immediate neighbor represent Nigeria interest in the welfare of its neighbor countries which is other wisely known as the ring countries, also the security of the West African sub region such as the sixteen Economic Community of West African States (ECOWAS) countries constitute the next operational environment, the African political milieu represents the interest of Nigeria and its neighboring countries of such as countries in the African Union. Another political environment is the organization of petroleum exporting countries from which Nigeria derives its source of revenue for budget, infrastructural development and security financing. The last which is the international system governs the Nigerian foreign and defense policies.

From the forgoing, it becomes clear that a military dimension of the foreign policy objectives must be needed to ensure our military readiness to meet the requirements of the preceding foreign policy objectives. Therefore, the Nigerian Defense Policy objectives were formulated and subjoined to the foreign policy as follows;

1) Establishing a credible armed forces. 
2) Development of a strong industrial base.

3) Formulating strategic contingency plans.

4) Effective intelligence network.

5) A functional national reserve/mobilization scheme and

6) Formulation of collective security system.

In otherwise the Nigerian Defense policy is tailored to complement the foreign policy in its relations with its neighbors and the world at large in which both are carefully based on national interest and security objectives (Ezeukwu, 1998). Many factors determine the shape of Nigeria's security decision making process among which are global approach to peace, the place of Africa in the world order, border security, foreign military influence and terrorism. This is the more reason why Nigeria designs its concentric circle of foreign policy in dealing with its neighbors and global world entirely within the matrix of international relations, national defense and collective security (Oshuntokun, 2003).

The Nigerian Defense Policy provides a theoretical basis of the national defense policy as "designed to guarantee national security and threats and aggression. While primary concern is to avoid war through diplomacy and deterrence. The nation will ensure that the armed forces possess the capability to successfully defend the Nigerian territory and her people. This portends that natural defense policy is to serve the natural interest of Nigeria which contains the core values that involve the survival of the Nigerian society and its population, political sovereignty and territorial independence.

Considering the dynamic of political and socio economic factors with the antecedent of insurgency and terrorism, it may appear that Nigeria is not at peace. It has come to the point the Nigeria's defense policy and all other security apparatus may not cope. Terrorism has engulfed a wider spectrum of dangerous activity highly international in scope with self-evident that it is not something any country can deal with by national strategy alone. Terrorism in Nigeria appears in different dimensions from kidnapping for ransom to assassination, robbery and compounded radicalized religious movement. Nigeria in its defense policy relies heavily on deterrence against such insecurity on the following principles: The nation shall maintain a credible defense capability and communicate her intentions in consonance that prevailing circumstances in order to ensure that potential aggressors are kept in no doubt of the willingness to use the Armed forces and all weapons at their disposal. Force modernization and development for the next few years shall, therefore give priority to accusation of deterrence capability from its natural defense policy. It appears there is one reliance on unconventional matrix using military as a source of deterrence. Nigerians should realize that military might in the absence of economic development, integrating, employment; excellent infrastructure and superior technology cannot withstand terrorism. Terrorist possess full resources, technology and motivation to fight protracted war against Nigeria.

Moreover, Nigeria is witnessing economic weakness to support its defense policy in the face of growing activities of Niger Delta militant holding hostage 
the multinationals, vandalizing the one pipeline which hampers technological and economic development. This is the more reason why Galtung (1975) disagreed with the application of military might in the absence of other resources in achieving national security when he said:"Security is not found in terms of nation state might but in terms of holistic understanding that moves beyond the currency of military power with state a key factor". In the midst of these appealing situations facing Nigeria defense policy only works on paper not on practical terms. The ranks of terrorist networks are rapidly increasing due to the absence of opportunity in societies hungry for hope. The exponential growth in the youth population in many Muslim-majority countries has not been matched by economic opportunities or the provision of basic services to their populations. Tensions are rising, particularly in countries where autocrats pay lip service to dissent while tightening their grip on power. Many young men are taught to hate the United States madrassas-religious schools-that can serve as radical Incubators. They have what at present seems to be an endless supply of recruit for a cause that extols death in its service. Tactically, success in our efforts to prevent attacks and control the spread of non-state actors like al Qaeda requires us to set aside policies traditionally used against our enemies. Deterrence will not work against the radical extremist core of terrorist networks. The United States cannot strike at their territory. They are elusive and hydra-headed, growing new branches even as we cut off others. They appear infinitely patient. And they are actively seeking to acquire nuclear or biological weapons to attack us. Disassembling the global terrorist networks requires a different, more nimble use of deadly force, and we must do everything we can to eliminate their hardinner core. We must also counter the supportive second ring that supplies the terrorists with the money and arms they need to stage attacks. Finally, we must launch a long-term campaign to undermine the basis of their recruiting efforts - to demonstrate through concrete action that the United States can be a force for good in the Muslim world and elsewhere and to bring their passive supporters to our side by the power of our values and example.

Again Nigeria's defense policy may have forgotten the global change in military revolutionary affairs in which military technological alone cannot cope with terrorists grand strategy of asymmetric warfare, suicide bombing, kidnapping and destruction of lives and properties. Terrorism is cheap, dangerous, deadly and with fair amount of luck and quite effective. Moreover, terrorism has stolen the advantage of globalization ahead of Nigeria defense policy to penetrate the world including Nigeria. Globalization has reduced the world into microscopic scientific village. It has also called for a change of shifting the interpretation of the concept of defense policy which is in moribund due to advancement in all forms of intelligence, strategy, information, surveillance and suicide bombing.

Today, the power of terrorism defiles the sheer force of military of any state. The 9/11 attack on America despite its economic and technological know-how brings to light the embarrassing limitations of the conventional security theory of national defense policy (Hook \& Spanier, 2016). The danger of international 
environment pose to Nigeria also fuels terrorism. Great powers like America, Britain and Russia are spreading their tentacles and ideology to entrench themselves into Nigerian economy and take total control. It may not be surprising if any of these rivalries is financing terrorism to break Nigeria for its own advantage. On the second question, developments since the attacks of 9/11 suggest that our current government has failed to take advantage of technology and maintain a much-needed perspective. It lacked the communications technology that allows us to penetrate the world and gives us a chance to win the long-term "Battle of ideas" with Muslim extremists. In addition to this technological shortcomings, Nigerian government also lost focus on the basics necessities that protect armed forces in battle and also ignored critical manpower needs. The fact remains that the human faces who are the military to enforce the deterrence may not be well motivated, lives not insured and facilities to cope for deterrence are not readily available. And presented with a balanced picture and doubts about intelligence alleging the political motivation of terrorism in Nigeria, the architects of the war against terrorism in Nigeria dismissed it and created their own reality. It is no exaggeration to say this record of ignorance, certainty and willful manipulation has been devastating to our national security. Technology has given Nigerian government powerful tools to save lives, but this may likely dampen the enthusiasm of the military men in making deterrent effective against terrorism (Amitav, 2004).

Subsequently we cannot ignore the implication that the short comings of the defense policy may have on Nigerian security. It may render Nigeria's government pariah and unsafe for foreign travelers and investors. Boko haram terrorism may generate to tribal war. Nigeria is an economically potential nation in which foreign powers are interested. It may generate to the point that if foreign military affairs intervene on fund of collective security we may be exposing our economic potentiality into danger. There may also be tendencies foe super powers to take the advantage of terrorism to break Nigeria. Internally, it instills fear and apprehension on the Nigerian citizen and foreigners with restricted movement in trading and tourism. It also destroys government image, national infrastructure and impede national development. It may be said that the Nigerian defence policy still faces challenges that remain unresolved. This involves the imperative necessity to making explicit judgment about the scope and direction of defence policy commitment as well the condition for processing the ability (structure, magnitude, and institutional parameters of Nigeria's defence establishment) to meet the functions and challenges (Bassey \& Dokubo, 2011).

\section{Implication for National Security}

Terrorism has serious implication for Nigerian national security due to the fact that it has come to stay as apolitical weapon to fight the government in order to yield to their demand or cause political instability. Again it has shown the ineptitude of the Nigerian government in fashioning out reasonable conflict resolu- 
tion mechanism to curb terrorist activities rather than monetary bargaining in settling issue. Moreover, terrorists' activities have almost reduced Nigeria into failed state that cannot guarantee the security of its citizens in the face of kidnapping, wanton destruction of lives and properties with lack of development in both public and private sectors of its economy. Terrorism in Nigeria is now a weapon of political vendetta by the opposition parties in Nigeria to mare the political image of the incumbent regime. Serious political campaign on the failure of incumbent regime is an added advantage to oust the ruling party from power. Another implication is the politicization of the Nigerian security outfits in which various tribes within the security settings may have viewed the activities of terrorists in Nigeria with different perspectives; some may have seen it as favouring religion grievances while others may also see it as unjust treatment of certain sector in Nigeria .The irony of it all is that it is rumored that some serving and discharged soldiers are likely to be well disposed to terrorism by aiding them with military logistics. Added to this is the fabulous military budget wasted on terrorism which drains national reserves in which those who are to manage the budget cannot account for how it is being spent to curb terrorism in the face of embezzlement, lack of accountability and power politics. Nigeria government in handling terrorism lacks political context of war for the fact that war against terrorism is beyond the number of casualties recorded in favour of government against terrorism but how government can manage conflict with minimal destruction, settle the affected population, political sensitization of the populace against terrorism, employment, motivation of the soldiers fighting against terrorism and joint efforts of all political parties without parties' bias. It can also be said that Nigeria security are not well familiar with the intelligence and strategy to fight terrorism due to the dangerous dimension it operates.

\section{Conclusion}

It appears as if the Nigeria's defense policy depends solely on deterrence without taking cognizance of the volatile insecurity issues in which terrorism takes the lead. Global environment is experiencing dynamic changes in threat issues and military revolution in which the Nigeria's defense policy does not take into consideration and if taken at all is at the detriment of sufficient technology, motivation, economic development and proper allocation of resources. Terrorism is a dangerous phenomenon in which Nigeria must be addressing its defense policy in line with global environment.

\section{Recommendations}

With the dynamism in the contemporary issues in world affairs in which terrorism stands as the most dangerous, violating all the principles and ethics of war without limited boundary. It is necessary for the Nigeria government to overhaul its defense policy. Deterrence alone cannot cope with the magnitude of crises that are affecting world peace and security. The Nigeria's Defense policy in re- 
cent time must not be confined to technical judgment of exhaustively military land but take account of geographical and social influence and venture deeply into the realms of economic and technology. Above all it must concern itself with the need for constraint charge and adaptation.

\section{Conflicts of Interest}

The authors declare no conflicts of interest regarding the publication of this paper.

\section{References}

Alabi, D. O. (2013). Issues and Problem in Nigerian Defence Policy in the 1990s: Acritical Review. Nigeria Army Journal, 3, 128-143.

Amitav, M. (2004). Technology and Security in the 21st Century: A Demand-Side Perspective. Stockholm International Peace Research Institute Research Report No. 20, Oxford, New York: Oxford University Press.

Apata, T. K. (2011). Terrorism, Treat and Emergency Management, Lagos, Devine Methodology Concept.

Asobie, H. A. (2014). The Theoretical and Doctrinal Foundation of Nigeria's Defence Policy in Journal of International Studies (pp. 17-34). Nsukka: University of Nigeria.

Bassey, C. O., \& Dokubo, C. O. (2011). Defense Policy of Nigeria: Capability and Contex, USA. Bloomington, IN: Author House.

Bodunde, D. O. (2006). Leadership Personality and Nigeria's Foreign Policy: A Case Study of President Olusegun Obasanjo 1999-2005. Ado Ekiti: A Project for the Award of M.Sc. International Relations of the University of Ado Ekiti.

Dyke, V. V.

https://www.yourarticlelibrary.com/international-politivs/national-interest-meaning-c omponent-andmethods $/ 48487$

Ezeukwu, G. (1998). Understanding International Relations, Enugu, Nigeria. Enugu: CPA and Gold Publishers.

Fage, S. K. (2016). Nigeria Regional Policy: Ideal and Aspirations, Defence. Journal of the Nigeria Defence Academy, 5, 1-18.

Fried Lander, A. R. (1984). Terrorism: Document of International and Local Control. New York: Oceana Publication, Inc. Dobbs Ferry.

FRN (1999). The Constitution of the Federal Republic of Nigeria.

Galtung, J. (1975). Peace, Research, Education, Action. Vol. 1 of Essay in Peace Research. Copenhagen: Ejlers.

Holsti, K. J. (1983). International Politics: A Framework for Analysis. London: Prentice Hall International Inc.

Hook, S. W., \& Spanier (2016). American Foreign Policy since World War II, USA. Thousand Oaks, CA: Sage, CQ Press.

Hughes, F. D. (2006). What Is Environmental History? Cambridge: Polity Press.

Morgenthau (1973).

https://www.yourarticlelibrary.com/international-politivs/national-interest-meaning-c omponent-andmethods/48487

Ogaba, O. (2010). Security, "Globalization and Climate Change”: A Conceptual Analysis. In E. E. Osita, \& O. Ogaba (Eds.), Security in Nigeria (pp. 28-39). Lagos: NIIA. 
Okwori (2012). Foundation and Dynamics of National Security. Nigerian Journal of International Studies, 8, 8-9.

Oshuntokun, J. (2003). Nigeria and Her Neighbours: A Perspective and Prospective View. Guardian June 2003, A6-7.

The Nigeria's National Defense Policy NNDP 2006.

Whittaker, D. J. (2007). The Terrorism Reader (3rd ed.). Abingdon-on-Thames: Routledge.

William, P. D. (2008). Security Studies: An Introduction. London: Routledge, Taylor and Francis Group.

Woods, T. R. T. (1983). Violent Terror. City: New KSS Publication \& IYC. 